\title{
AN EMPIRICAL ANALYSIS OF RELATIONSHIP BETWEEN TOURISM AND ECONOMIC GROWTH: PANEL EVIDENCE FROM WESTERN BALKAN COUNTRIES
}

\author{
Vera Mirović ${ }^{1}$ \\ Branimir Kalaš ${ }^{2}$ \\ Nataša Pavlović ${ }^{3}$
}

DOI: https://doi.org/10.31410/tmt.2020.39

\begin{abstract}
Tourism is one of the most important sectors in the world and it has multiplier effects due to indirect implications to a wide variety of small, service-oriented businesses. This paper aims to determine the effects of the tourism sector on economic growth in terms of tourism share, international tourism receipts and international tourism arrivals. The subject of the chapter is estimating the effects of the tourism sector on economic growth in selected Western Balkan countries such as Albania, Bosnia and Herzegovina, Montenegro, North Macedonia and Serbia for the period 2007-2018. Results of the fixed effects model show tourism sector has significant and positive impact on economic growth in these countries for the observed period. Empirical findings manifest that governments in Western Balkan countries should focus on a higher share of the tourism sector in their economy in order to provide positive implications to economic development.
\end{abstract}

Keywords: Tourism, Economic growth, Panel data estimation, Western Balkan countries.

\section{INTRODUCTION}

$\mathrm{T}$ ourism is one of the largest industries in the world and this industry has an enormous effect on the national economy and people's lives (Petrevska, 2017). It implies that the tourism sectors are recognized to positively contribute to economic growth (Brida et al. 2020). In past decades there was a dramatic growth in global tourism in terms of international arrivals and receipts (Lim et al. 2018). Ongan and Gozgor (2018) notice that international tourism has become one of the leading determinants to affect economic development. Visitors to tourism destinations spend money on goods and services, making economic effects on value-added, income, and employment (Tafel and Szolnoki, 2020). Shahzad et al. (2017) highlight that the tourism industry generates employment and tax revenues as well as stimulates investment in human capital, infrastructure and technology where tourism plays a significant role in stimulating consumption, promoting trade and, improving international communication (Qian et al. 2018).

Cerović Smolović et al. (2018) defined the concept of sustainable tourism development that implies a tourism sector enabling high-quality products, satisfying the needs of tourists and keeping tourism resources for future generations. Iatu (2018) emphasizes that sustainable tourism is the concept of visiting a place as a tourist and creating only a positive effect on the environment, society and economy.

\footnotetext{
1 Faculty of Economics in Subotica, University of Novi Sad, Segedinski put 9-11, 24000, Subotica, Serbia

2 Faculty of Economics in Subotica, University of Novi Sad, Segedinski put 9-11, 24000, Subotica, Serbia

3 Faculty of Economics and Engineering Management in Novi Sad, Cvećarska 2, 21000, Novi Sad, Serbia
} 
Zhang and Chan (2019) identified governments as the parties responsible for initiating sustainable tourism platforms. Determining the drivers of tourism growth is important for explaining the growth patterns of tourism and creating sustainable tourism development (Zha et al. 2019). Yfantidou and Matarazzo (2016) argue that tourism is one of the most important industries in the world in terms of environmental protection and socio-cultural conservation. Lu et al. (2018) point out that the tourism industry, regional economy and ecological environment form mutually interactive and interdependent relationships. Bianchi and de Man (2020) argue that tourism development creates new forms of value and reshuffles the internal distribution of capital, land use and organization of labour. Seetanah et al. (2018) argued that the implementation of concurrent policy measures based on stimulating air access liberalization and the promotion of marketing efforts have positive implications to tourism demand. Summers et al. (2019) emphasize the government's support to communities, especially in remote communities in order to provide opportunities for collaboration and stimulating business innovation.

Many developing economies, that are successfully exploiting their natural resources for tourism purposes, increased international receipts level due to tourism development (Chingarande, Saayman, 2018). Tourism is an important driver of the use of natural resources, cultural resources, traditions and local customs and it provides connecting people from all over the world, as well as creating profit and contributing to economic growth and employment (Băndoi et al. 2020). Banerjee et al. (2018) highlight that tourism is one of the fastest-growing economic sectors that generate $10 \%$ of GDP and $30 \%$ of export in the services sectors at the global level. Zhou and Chan (2019) highlighted the education of employees and entrepreneurs about the complex nature of the tourism sector and the importance of sustainable development. Tourism is an essential economic engine and provides socioeconomic development creating employment opportunities (Usmani et al. 2020). Dwyer et al. (2015) highlight tourism destinations in South Easter Europe as the main origin and source market for future tourism flows. Kalaš et al. (2019) point out that the tourism industry in Serbia and countries in the region such as Hungary, Croatia, Slovenia and Romania reflect the great interest in tourism development.

The structure of this chapter is as follows. After the introduction, there is a short preview of the implications of the COVID-19 pandemic on the tourism sector in the world. Further, there is a literature review where previous empirical studies have examined the relationship between tourism and economic growth. The third part is methodology and data which determines variables, develops hypotheses and makes a panel regression model. The fourth part is the descriptive and empirical analysis of gross domestic product per capita, tourism share in GDP, international tourism receipts and international tourism arrivals in Western Balkan countries for the period 2007-2018. This part includes various panel data estimations such as pooled ordinary least squares, fixed-effects model and the random-effects model. The last part summarizes the findings and conclusions by providing informational support to policymakers in these countries from the aspect of the nexus between tourism and economic growth.

\section{THE IMPLICATIONS OF COVID-19 PANDEMIC ON TOURISM SECTOR}

In light of the COVID-19 pandemic that has now become a global economic and social problem, there are many issues about its impact on the tourism sector in the short and long term (Romagosa, 2020). As the COVID-19 pandemic is ongoing and has serious implications for global economic flows, the effect of this virus on the tourism sector needs to be considered. As this pandemic swept across the world, travel limitations and lockdowns were introduced in many 
economies (Qiu et. al, 2020). COVID-19 pandemic is widely recognized as a challenge for the travel and tourism sector (Higgins-Desbiolles, 2020) and this virus is highly transmittable and affects the world's economy with the travel and tourism industry one of the most ravaged sectors (Yang et al. 2020). Rodríguez-Antón and Alonso-Almeida (2020) argue that the epidemic caused by COVID-19 is the largest pandemic that has affected the world in the last hundred years. Galvani et al. (2020) argue that it is not too surprising the effect of COVID-19 on the tourism and travel industry, because these components were exposed by positive and negative implications of the globalization process. This pandemic caused a lockdown around the world that was reflected in the reduction of travel and tourists number and the COVID-19 outbreak has put on hold the whole tourism and travel industry (Niewiadomski, 2020). Tourism is most affected in countries where the share of this sector is significant in the gross domestic product. Tourism is especially exposed to restricted mobility and social distancing (Gössling et al. 2020) where Uğur and Akbiyik (2020) point out that the tourism industry is easily affected by global crises where Lapointe (2020) notice that 166 countries restrict entry into their national territories and cause empty tourism destinations. Farzanegan et al. (2020) argue that COVID-19 has important policy effects for major tourist destinations such as France, Italy and Spain as well as for China and the United States that have a high level of outbound tourism. Accordingly, Polyzos et al. (2020) determined a significant drop in tourist arrivals from China to the United States and Australia. Prideaux et al. (2020) emphasize that a return to pre-pandemic growth level will take time and it depends on the depth and extend of the recession caused by the COVID-19 pandemic.

\section{LITERATURE REVIEW}

Tourism is increasingly a significant part of the economy as well as the source of income in today's conditions of globalization and open economy. Therefore, the relationship between tourism and economic growth represents an important issue for policymakers in creating an adequate tourism strategy in order to provide sustainable economic development. Many empirical studies have examined the relationship between tourism and economic growth (Belloumi, 2010; Tang and Tan, 2013; Dogru et al. 2017; Wu and Wu, 2018; Mitra, 2019; Yazdi, 2019; Khan et al. 2020; Usmani et al. 2020). Belloumi (2010) determined cointegration between tourism and economic growth in Tunisia for the period 1970-2007 as well as unidirectional causality from tourism to economic growth measured by gross domestic product in the observed period. Saleh et al. (2013) examined the relationship between tourism and economic growth in Bahrain, Jordan and Saudi Arabia for the period 1981-2008. Their findings indicated the long-run relationship between tourism growth and economic growth measured by gross domestic product. Tang and Tan (2013) identified cointegration between tourism and economic growth in Malaysia to 12 different tourism markets from 1995 to 2009. Tugcu (2014) argue that tourism is an essential source of foreign exchange that is used for financing economic growth where Bezić and Nikšić Radić (2017) confirmed tourism sector significance to foreign direct investments in order to provide sustainable economic growth. Dogru et al. (2017) examined the relationships between tourism development and economic growth in the United States, France, Spain, China, Italy, Turkey and Germany for the period 1995-2012. Their results confirmed that tourism development and economic growth are independent in Germany.

Similarly, tourism development stimulates economic growth in China and Turkey, whereas the reverse relationship is identified in Spain for the observed period. Selimi et al. (2017) analyzed the effects of tourism on economic growth in Western Balkan countries for the period 19982014. Their findings showed the significant and positive impact of tourism on economic growth 
in analyzed countries where a $1 \%$ increase of tourist arrivals enhances economic growth by $0.08 \%$. Similarly, Hysa and Gjergi (2018) examined the relationship between tourism and economic growth in Western Balkan countries from 2000-2014. Although visitor exports and capital investment are significant to economic growth, their results showed that in total there is no long-run nexus between tourism and economic growth in these countries. Wu and $\mathrm{Wu}(2018)$ examined the causality between tourism and economic growth in 11 Asian countries. Their results showed unidirectional causality from tourism to gross domestic product in Cambodia, China, and Malaysia, while reverse causality is identified in Hong Kong, Indonesia, Philippines, and South Korea for the observed period.

Aratuo and Etienne (2019) analyzed the relationship between economic growth and tourism-related sub-industries such as accommodation, air transportation, shopping, food and beverage, other transportation, recreation and entertainment in the United States for the period 1998-2017. Their findings confirmed unidirectional causality from economic growth to each of the sub-industries for the observed period. They suggest that tourism investment could be important in the long-run even during economic stagnation. Mitra (2019) analyzed the causal relationship between tourism growth and economic growth in 158 countries for the period 2001-2017. Their empirical findings show that bidirectional causality between these variables is identified in three subsamples for the observed period.

Yazdi (2019) researched the causality between tourism and economic growth in Iran from 19812014 and his analysis confirmed unidirectional causality running from tourism to economic growth. Khan et al. (2020) point out that tourism is considered a competent driver of development in emerging economies and Ehigiamusoe (2020) defined the tourism-led growth hypothesis in terms of positive implications of the tourism sector on economic growth. Khan et al. (2020) revealed the significant and positive effect of economic growth on tourism in Pakistan. Empirical results show that a $1 \%$ increase in economic growth enhances tourism by $1.9 \%$ in the long-run while the same increase in economic growth raises tourism by $1.32 \%$ in the short-run. Santamaria and Filis (2019) found a significant impact of tourism on economic growth in Spain and their analysis confirmed the tourism-led growth hypothesis.

Tang et al. (2019) investigated the effect of tourism and financial development on economic growth in Hong Kong, South Korea, Singapore and Taiwan for the period 1984-2016 and their empirical analysis indicated that these variables are important for growth in Asia. Usmani et al. (2020) have examined the effect of tourism arrivals and tourist expenditure on economic growth in Brazil, Russia, India and China for the period 1995-2016. Their findings confirmed that tourist expenditure positively affects economic growth as well as the existence of bidirectional causality between these variables.

\section{METHODOLOGY AND DATA}

The chapter includes annual data obtained from World Bank (WB) and International Monetary Fund (IMF) for five Western Balkan countries (Albania, Bosnia and Herzegovina, Montenegro, North Macedonia and Serbia) for the period 2007-2018.

The chapter implies panel data estimation where gross domestic product per capita is the dependent variable, while tourism share in GDP, international tourism receipts and international tourism arrivals are independent variables. 
Table 1. Variable definition

\begin{tabular}{|l|c|c|c|c|}
\hline Variable & Notation & Calculation & Source & Expected effect \\
\hline Dependent variable & GDPpc & US & IMF & $/$ \\
\hline $\begin{array}{l}\text { Gross domestic } \\
\text { product per capita }\end{array}$ & TRS & $\%$ of GDP & WB & + \\
\hline Independent variables & ITR & WB & + \\
\hline $\begin{array}{l}\text { Gross domestic } \\
\text { product }\end{array}$ & International \\
tourism receipts & ITA & & WB & + \\
\hline $\begin{array}{l}\text { International } \\
\text { tourism arrivals }\end{array}$ & T & & \\
\hline
\end{tabular}

Source: Authors illustration

The chapter includes four hypotheses based on defined research's objectives that are developed as follows:

$\mathbf{H}_{\mathbf{0}}$ : Tourism sector has a significant and positive effect on economic growth in Western Balkan countries.

$\mathbf{H}_{1}$ : Greater level of tourism share in GDP significantly increases economic growth in Western Balkan countries.

$\mathbf{H}_{2}$ : Greater level of international tourism receipts significantly increases economic growth in Western Balkan countries

$\mathbf{H}_{3}$ : Greater number of international tourism arrivals significantly increases economic growth in Western Balkan countries.

The chapter includes various panel models such as pooled least squares, fixed effects model and random-effects model. The random-effects model was identified as an appropriate model in order to estimate the impact of explanatory variables.

The model can be presented as:

$$
\mathrm{GDPpc}_{\mathrm{it}}=\beta_{1}+\beta_{2} \mathrm{TRS}_{\mathrm{it}}+\beta_{3} \mathrm{ITR}_{\mathrm{it}}+\ldots \beta_{4} \mathrm{ITA}_{\mathrm{it}}+\varepsilon_{\mathrm{i}}+\mu_{\mathrm{it}}
$$

where GDPpc - gross domestic product per capita, TRS - tourism share in the gross domestic product, ITR - international tourism receipts, ITA - international tourism arrivals, N denotes the number of observations, T number of period, $\alpha$ constant, $\beta_{1}$ a random variable with a mean value of parameters and $\varepsilon_{i}$ - random error with mean value 0 and variance $\sigma_{\varepsilon}^{2}, \mu$-random error.

\section{EMPIRICAL ANALYSIS AND RESULTS}

This segment includes descriptive statistics, panel unit root tests, multivariate analysis results and panel regression models such as pooled ordinary least squares, fixed effects model and random effects model in order which explanatory variables are significant for economic growth in Western Balkan countries. Before empirical analysis, there are trends in tourism share in GDP, international tourism receipts and international tourism arrivals for the period 2007-2018.

Figure 1 shows economic growth in Western Balkan countries measured by annual gross domestic product rate for the period 2007-2018. The average GDP growth rate was $2.65 \%$ for the observed period while Albania recorded the highest economic growth by $3.33 \%$ at an average 
level. It can be seen that all countries, except Albania, had a negative growth rate during 2009 and 2010, while the highest negative value is identified in Montenegro (-5.5\%). It is important to notice that in last year (2018) selected countries recorded average economic growth of 3.26\% where Montenegro and Serbia recorded growth above 4\%. Likewise, Albania and Bosnia and Herzegovina had a gross domestic product rate above 3\%, while North Macedonia recorded economic growth near $0.3 \%$.
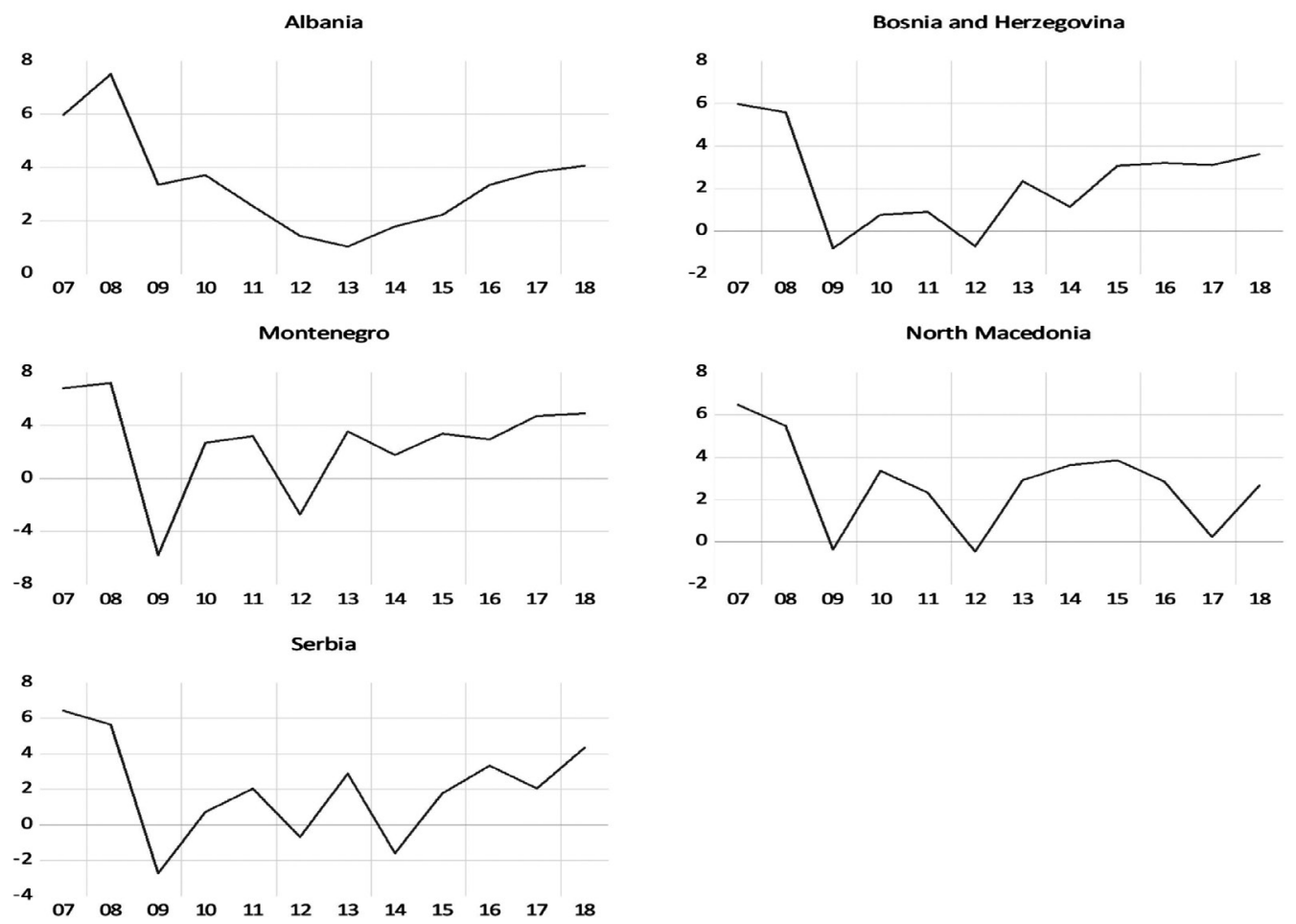

Figure 1.

GDP growth rate in selected Western Balkan countries

Source: Authors calculation

After presenting economic trend in Western Balkan countries there is a tourism share in the gross domestic product in observed countries from 2007 to 2018. Analyzing by countries it can be noticed that tourism share increased for $31 . \%$ of the gross domestic product in Montenegro during the observed period. This is the highest growth compared to other countries while Albania and Serbia recorded similar growth of this indicator by $2.8 \%$ and $2 \%$ in gross domestic product. On the other hand, only Bosnia and Herzegovina had a smaller share of tourism compared to 2007 and 2018 and this fall was $0.8 \%$ of gross domestic product. Also, it is necessary to emphasize that the relative trend of tourism share in the gross domestic product was $1.74 \%$ for the period 2007-2018 which implies a positive tourism trend in this region.

Analyzing the level of international tourism receipts and the number of international tourism arrivals in selected Western Balkan countries, we can see that the average number of international tourist arrivals increased by $10.17 \%$. Although these countries recorded growth of tourism arrivals, the average level of international tourism receipts was negative. Namely, international tourism receipts declined by $0.78 \%$ at the average level for observed countries in the analyzed period. The highest average growth of international tourism receipts is identified in Montenegro (2.11\%) while other countries recorded an average negative growth rate of this indicator. Finally, Albania recorded the highest average growth rate of international tourism arrivals $(15.05 \%)$. 

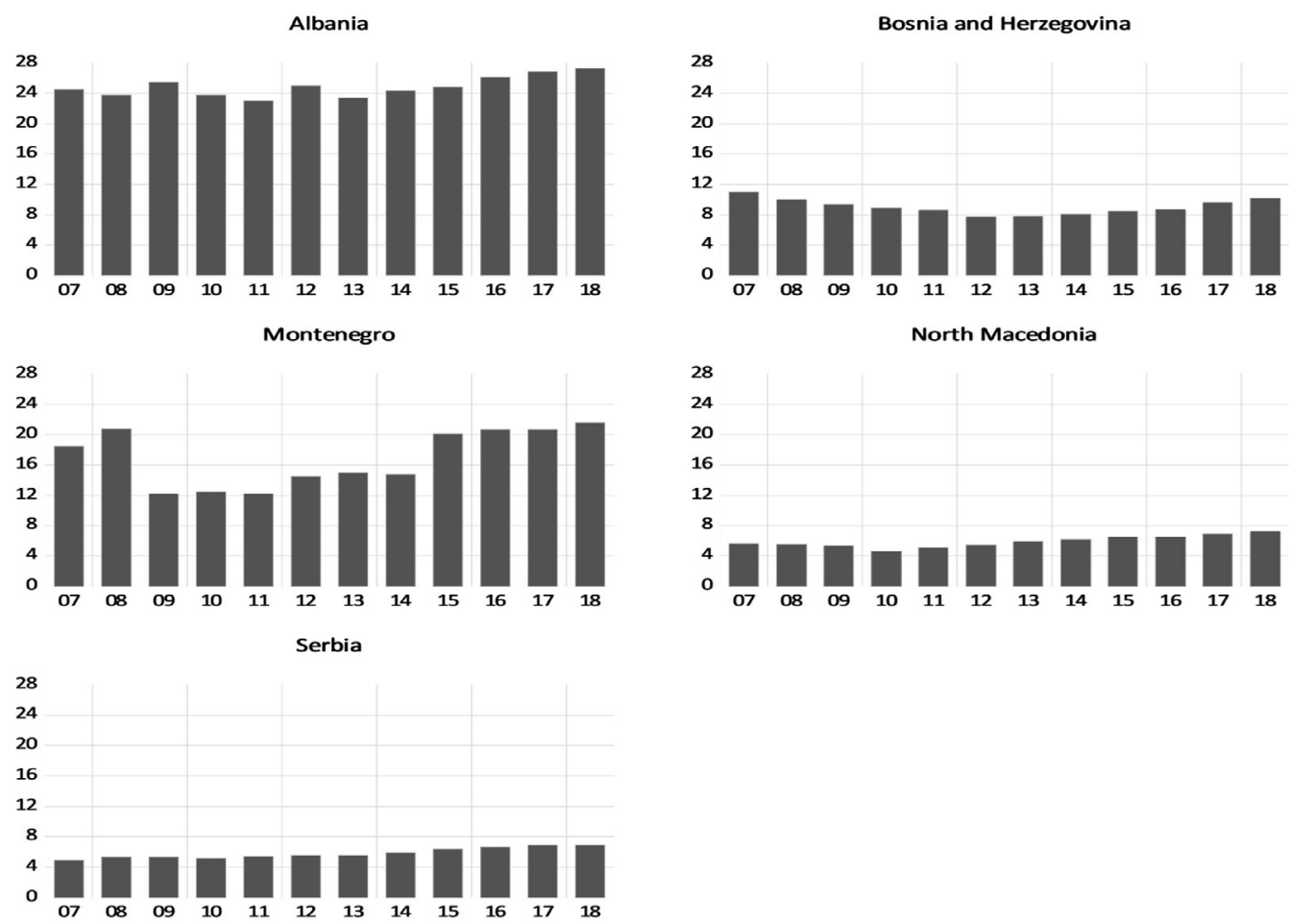

\section{Figure 2.}

Tourism share in selected Western Balkan countries (\% GDP)

Source: Authors calculation
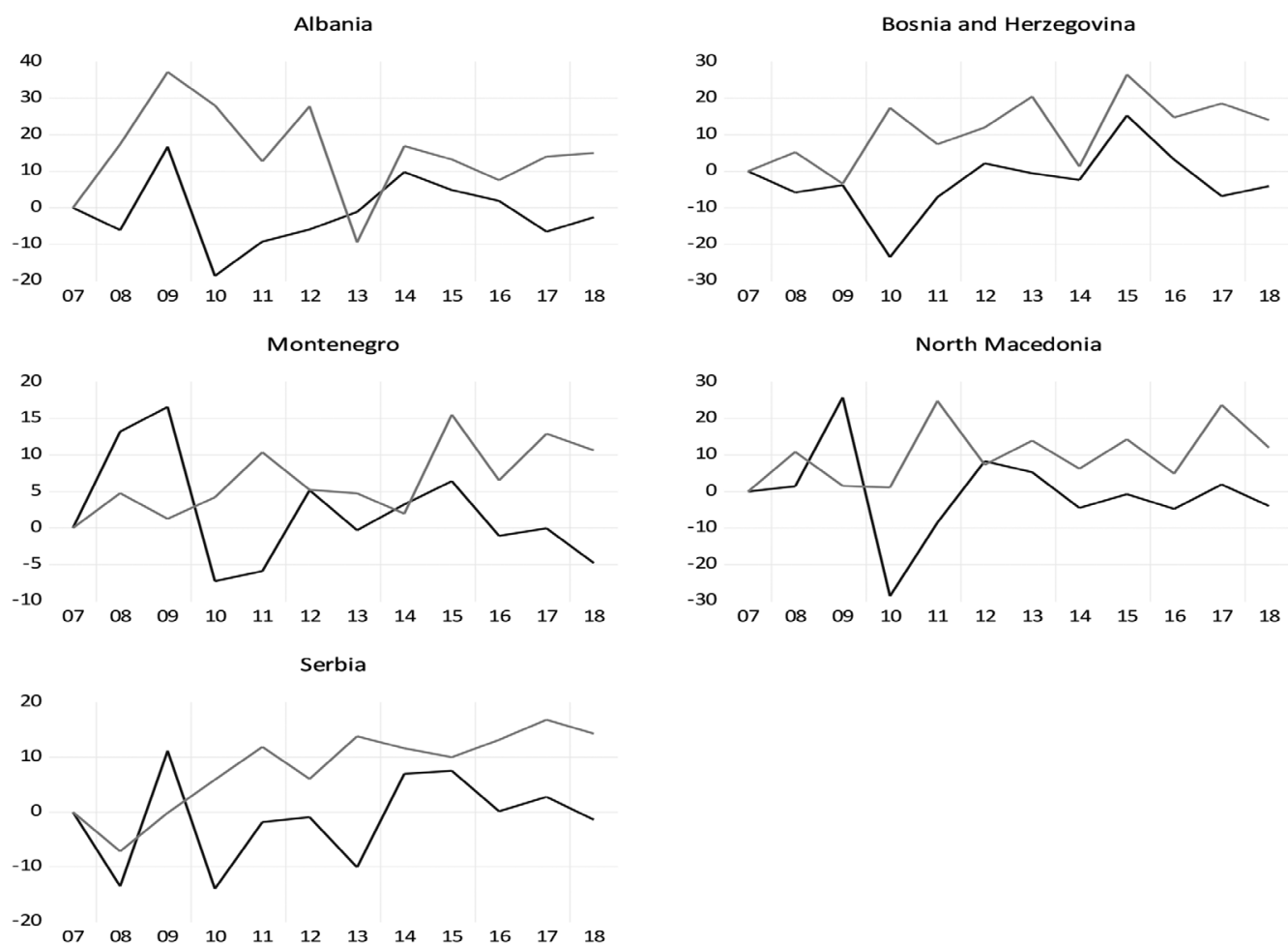

Figure 3.

Relative changes of international tourism receipts and international tourism arrivals Source: Authors calculation 
Table 2. Descriptive statistics

\begin{tabular}{|c|c|c|c|c|}
\hline Variable & GDPpc & TGDP & ITR & ITA \\
\hline \multicolumn{5}{|c|}{ Albania } \\
\hline Mean & 10068.22 & 24.87 & 52.26 & 2588750 \\
\hline Std. Dev. & 1053.88 & 1.36 & 6.04 & 1332158 \\
\hline Max & 11841.9 & 27.3 & 65.76 & 5340000 \\
\hline Min & 8154.2 & 23 & 45.13 & 1062000 \\
\hline \multicolumn{5}{|c|}{ Bosnia and Herzegovina } \\
\hline Mean & 10318.8 & 9.04 & 14.09 & 552666.7 \\
\hline Std. Dev. & 951.21 & 1.02 & 2.37 & 252480.2 \\
\hline Max & 12069.96 & 11 & 18.75 & 1053000 \\
\hline Min & 9000.42 & 7.7 & 11.97 & 306000 \\
\hline \multicolumn{5}{|c|}{ Montenegro } \\
\hline Mean & 14677.35 & 16.97 & 51.09 & 1371833 \\
\hline Std. Dev. & 1109.97 & 3.77 & 3.97 & 352942.4 \\
\hline Max & 17035.92 & 21.6 & 55.11 & 2077000 \\
\hline Min & 13427.69 & 12.2 & 41.74 & 984000 \\
\hline \multicolumn{5}{|c|}{ North Macedonia } \\
\hline Mean & 12434.58 & 5.89 & 5.69 & 403583.3 \\
\hline Std. Dev. & 983.32 & 0.78 & 0.73 & 154965.4 \\
\hline Max & 13964.12 & 7.2 & 7.74 & 707000 \\
\hline Min & 10929.94 & 4.6 & 5.05 & 230000 \\
\hline \multicolumn{5}{|c|}{ Serbia } \\
\hline Mean & 13725.7 & 5.82 & 7.69 & 9984666.7 \\
\hline Std. Dev. & 905.65 & 0.7 & 0.68 & 355356.5 \\
\hline Max & 15596.91 & 6.9 & 9.13 & 1711000 \\
\hline Min & 12424.63 & 4.9 & 6.59 & 645000 \\
\hline \multicolumn{5}{|c|}{ Total } \\
\hline Mean & 12244.93 & 12.52 & 26.16 & 1260400 \\
\hline Std. Dev. & 2076.92 & 7.68 & 21.45 & 1127427 \\
\hline Max & 17035.91 & 27.3 & 65.76 & 5340000 \\
\hline Min & 8154.2 & 4.6 & 5.05 & 230000 \\
\hline
\end{tabular}

Source: Authors calculation

Based on descriptive statistics by Western Balkan countries, it can be seen that the average GD$\mathrm{Ppc}$ is $12.244,93$ US for the observed period. These countries have a share of the tourism sector of $12.52 \%$ in GDP from 2007 to 2018. Further, international tourism receipts are $26.16 \%$ at the average level, while average international tourism arrivals are 1.180 .300 in these countries. Analyzing by country, the highest average level of GDPpc is identified in Montenegro (14.4677 US), while Albania had the smallest GDPpc (10.068 US). On the other hand, Albania recorded the highest number of international tourism arrivals (5.340.000 in 2017), while the smallest number of international tourism arrivals is determined in Macedonia (240.000 in 2007).

Table 3 shows multivariate analysis results for Western Balkan countries in terms of estimating the different levels of tourism share in GDP, international tourism receipts and international tourism arrivals for the period 2007-2018. Analyzing obtained values of Pillai's Trace $=0.000$ for explanatory variables TRS, ITR and ITA, we can conclude that there is a significant difference in tourism share in GDP, international tourism receipts and international tourism arrivals in selected Western Balkan countries for the observed period. 
Table 3. Estimating difference level of tourism indicators

\begin{tabular}{|c|c|c|c|c|c|}
\hline \multirow{2}{*}{ TRS } & \multicolumn{2}{|c|}{$\mathrm{W}=$ Wilks' lambda } & \multicolumn{3}{|c|}{$\mathrm{L}=$ Lawley-Hotelling trace } \\
\hline & \multicolumn{2}{|c|}{$\mathrm{P}=$ Pillai's trace } & \multicolumn{3}{|c|}{$\mathrm{R}=$ Roy's largest root } \\
\hline Source & Statistic & $\mathrm{F}(\mathrm{df1})$ & $\mathrm{F}(\mathrm{df} 2)$ & $\mathrm{F}$ & Prob $>F$ \\
\hline $\mathrm{W}$ & 0.0576 & 4.0 & 55.0 & 225.11 & 0.0000 \\
\hline $\mathrm{P}$ & 0.9424 & 4.0 & 555.0 & 225.11 & 0.0000 \\
\hline $\mathrm{L}$ & 16.3716 & 4.0 & 55.0 & 225.11 & 0.0000 \\
\hline $\mathrm{R}$ & 16.3716 & 4.0 & 55.0 & 225.11 & 0.0000 \\
\hline Residual & \multicolumn{5}{|c|}{55} \\
\hline Total & \multirow{2}{*}{\multicolumn{2}{|c|}{$\mathrm{W}=$ Wilks' lambda }} & \multicolumn{3}{|l|}{59} \\
\hline & & & \multicolumn{3}{|c|}{$\mathrm{L}=$ Lawley-Hotelling trace } \\
\hline & \multicolumn{2}{|c|}{$\mathrm{P}=$ Pillai's trace } & \multicolumn{3}{|c|}{$\mathrm{R}=$ Roy's largest root } \\
\hline $\begin{array}{l}\text { TTR } \\
\text { Source }\end{array}$ & Statistic & $\mathrm{F}(\mathrm{df} 1)$ & $F(d f 2)$ & $\mathrm{F}$ & Prob $>F$ \\
\hline $\mathrm{W}$ & 0.0238 & 4.0 & 55.0 & 562.90 & 0.0000 \\
\hline $\mathrm{P}$ & 0.9762 & 4.0 & 555.0 & 562.90 & 0.0000 \\
\hline $\mathrm{L}$ & 40.9380 & 4.0 & 55.0 & 562.90 & 0.0000 \\
\hline $\mathrm{R}$ & 40.9380 & 4.0 & 55.0 & 562.90 & 0.0000 \\
\hline Residual & & & 55 & & \\
\hline Total & & & 59 & & \\
\hline \multirow{2}{*}{ ITA } & \multicolumn{2}{|c|}{$\mathrm{W}=$ Wilks' lambda } & \multicolumn{3}{|c|}{$\mathrm{L}=$ Lawley-Hotelling trace } \\
\hline & \multicolumn{2}{|c|}{$\mathrm{P}=$ Pillai's trace } & \multicolumn{3}{|c|}{$\mathrm{R}=$ Roy's largest root } \\
\hline Source & Statistic & $\mathrm{F}(\mathrm{df1})$ & $F(d f 2)$ & $\mathrm{F}$ & Prob $>F$ \\
\hline $\mathrm{W}$ & 0.3731 & 4.0 & 55.0 & 23.10 & 0.0000 \\
\hline $\mathrm{P}$ & 0.6269 & 4.0 & 555.0 & 23.10 & 0.0000 \\
\hline $\mathrm{L}$ & 1.6804 & 4.0 & 55.0 & 23.10 & 0.0000 \\
\hline $\mathrm{R}$ & 1.6804 & 4.0 & 55.0 & 23.10 & 0.0000 \\
\hline Residual & \multicolumn{5}{|c|}{55} \\
\hline Total & \multicolumn{5}{|c|}{59} \\
\hline
\end{tabular}

Source: Authors calculation

Results from Table 4 show that panel series are stationary at level of $5 \%$ and provide making various panel regression models such as pooled ordinary least squares, fixed effects model and random effects model.

Table 4. Panel unit root test

\begin{tabular}{|c|c|c|c|c|}
\hline \multicolumn{5}{|l|}{ H0: Panels contain unit roots } \\
\hline H1: Panels are stationary & LLC test & IPS test & Hadri test \\
\hline Variables & Number of panels & -8.53 & -7.17 & 5.08 \\
GDPpc & \multirow{2}{*}{27} & $(0.000)$ & $(0.002)$ & $(0.000)$ \\
\hline \multirow{2}{*}{ TRS } & \multirow{2}{*}{27} & -2.22 & -1.93 & 1.52 \\
& \multirow{2}{*}{27} & $(0.000)$ & $(0.000)$ & $(0.000)$ \\
\hline \multirow{2}{*}{ ITR } & \multirow{2}{*}{27} & -2.37 & -1.06 & 2.62 \\
& \multirow{2}{*}{ ITA } & -8.96 & $(0.023)$ & $(0.004)$ \\
\hline
\end{tabular}

Source: Authors calculation

Table 5 shows the effect of tourism variables on economic growth measured by gross domestic product per capita in Western Balkan countries through POLS, FE and RE models. Results of Hausman test determined that the fixed effects model is appropriate for the analysis of explanatory variables on economic growth in the analyzed period. Fixed effects model explains $92 . \%$ 
variations of independent variables and indicated a significant effect of selected tourism determinants on gross domestic product per capita in observed countries. The selected model shows that TRS, ITR and ITA have a positive impact on GDPpc where a $1 \%$ increase of these variables enhances economic growth for $0.22 \%, 0.21 \%$ and $0.09 \%$. These empirical findings manifest that these countries should focus on a higher share of the tourism sector in GDP as well as a greater level of international tourism receipts and number of arrivals in order to provide a higher level of economic growth.

Table 5. Panel Data Estimation

\begin{tabular}{|c|c|c|c|c|c|c|}
\hline \multicolumn{7}{|l|}{ Models } \\
\hline Variable & \multicolumn{2}{|c|}{ POLS } & \multicolumn{2}{|c|}{$\mathrm{FE}$} & \multicolumn{2}{|c|}{$\mathrm{RE}$} \\
\hline GDPpc & Coeff & Prob. & Coeff. & Prob. & Coeff. & Prob. \\
\hline TRS & 0.35 & 0.001 & 0.22 & 0.000 & 0.21 & 0.000 \\
\hline ITR & 0.10 & 0.008 & 0.21 & 0.004 & 0.19 & 0.000 \\
\hline ITA & 0.14 & 0.000 & 0.09 & 0.000 & 0.09 & 0.000 \\
\hline $\mathrm{C}$ & 3.46 & 0.000 & 3.55 & 0.000 & 3.56 & 0.000 \\
\hline R-squared & \multicolumn{2}{|c|}{0.28} & \multicolumn{2}{|c|}{0.92} & \multicolumn{2}{|c|}{0.59} \\
\hline $\begin{array}{l}\text { Model } \\
\text { specification }\end{array}$ & \multicolumn{2}{|c|}{ Chi-Sq. Stat } & \multicolumn{2}{|c|}{ Chi-Sq. d.f. } & \multicolumn{2}{|c|}{ Prob. } \\
\hline Hausman test & \multicolumn{2}{|c|}{36.58} & \multicolumn{2}{|c|}{3} & \multicolumn{2}{|c|}{0.000} \\
\hline
\end{tabular}

Source: Authors calculation

\section{CONCLUSION AND DISCUSSION}

Tourism is an increasingly important sector in the world economy and positive implications of this sector should be used to provide faster economic growth and development. This also applies to Western Balkan countries that must be better positioned on the world tourist map by using natural resources and all available capacities. The relationship between the tourism sector and economic growth is an essential issue for policymakers in making an adequate tourism strategy. The chapter has estimated the effect of the tourism sector on economic growth in selected Western Balkan countries such as Albania, Bosnia and Herzegovina, Montenegro, North Macedonia and Serbia from 2007 to 2018. Empirical analysis includes three-panel estimation data such as pooled least squares model, fixed effects model and random effects model in order to determine the significance of the tourism sector in these countries. We have examined the effect of tourism share in the gross domestic product, international tourism receipts and international tourism arrivals on economic growth measured by gross domestic product per capita. Within selected models, Hausman test has presented that the fixed effects model is appropriate and it reflects that a $1 \%$ increase of TRS, ITR and ITA raise economic growth by $0.22 \%, 0.21 \%$, and $0.09 \%$ respectively. It means that $\mathrm{H}_{0}$ can be accepted because all tourism indicators have positive effects on economic growth. Likewise, $\mathrm{H}_{1}, \mathrm{H}_{2}$, and $\mathrm{H}_{3}$ can be accepted, where TRS, ITR and ITA have significantly enhanced the economic growth. These findings show that policymakers should focus on these tourism indicators in order to provide a positive impact on economic growth in Western Balkan countries. Future research will be focused on the knowledge-based platform in the tourism system in these economies (Popesku \& Pavlović, 2013; Paunović et al. 2020) in order to provide a scientific contribution from the aspect of this indicator. 


\section{REFERENCES}

Aratuo, D.,N., \& Etienne, X.L. (2019). Industry level analysis of tourism-economic growth in the United States. Tourism Management, 70, 333-340. DOI: 10.1016/j.tourman.2018.09.004

Băndoi, A., Jianu. E., Enescu, M., Axinte, G., Tudor, S., \& Firoiu, D. (2020). The Relationship between Development of Tourism, Quality of Life and Sustainable Performance in EU Countries. Sustainability, 12(4), 1-24. DOI: 10.3390/su12041628

Banerjee, O., Cicowiez, M., Morris, E.J., \& Moreda, A. (2018). Boosting tourism's contribution to growth and development: Analysis of the evidence. Review of Development Economics, 22(3), 1-25. DOI: 10.111/rode.12385

Belloumi, M. (2010). The relationship between tourism receipts, real effective exchange rate and economic growth in Tunisia. International Journal of Tourism Research, 12(5), 550-560. DOI: $10.1002 /$ jtr.774

Bezić, H., \& Nikšić Radić, M. (2017). Tourism foreign direct investment led tourism gross value added: a co-integration and causality analysis of Croatian tourism. Economic Research Ekonomska istraživanja, 30(1), 1443-1460. DOI: 10.1080/1331677x.2017.1340173

Bianchi, R.V., \& de Man, F. (2020). Tourism, inclusive growth and decent work: a political economy critique. Journal of Sustainable Tourism, 1-19, DOI: 10.1080/09669582.2020.1730862

Brida, J.G., Matesanz Gómez, D., \& Segarra, V. (2020). On the empirical relationship between tourism and economic growth. Tourism Management, 81, 1-11. DOI: 10.1016/j.tourman.2020.104131

Cerović Smolović, J., Janketić, S., Jaćimović, D., Bučar, M., \& Stare, M. (2018). Montenegro’s Road to Sustainable Tourism Growth and Innovation. Sustainability, 10(12), 1-20. DOI: $10.3390 /$ su10124687

Chingarande, A., \& Saayman, A. (2018). Critical success factors for tourism-led growth. International Journal of Tourism Research, 20(6), 1-19. DOI: 10.1002/jtr.2233

Dwyer, L., Armenski, T., Cvelbar, L.K., Dragićević, V., \& Mihalic, T. (2015). Modified Importance-Performance Analysis for Evaluating Tourism Businesses Strategies: Comparison of Slovenia and Serbia. International Journal of Tourism Research, 18(4), 327-340. DOI: $10.1002 /$ jtr.2052

Ehigiamusoe, K.U. (2020). Tourism, growth and environment: analysis of non-linear and moderating effects. Journal of Sustainable Tourism, 28(8), 1-20. DOI: 10.1080/09669582.2020.1729164

Farzanegan, M. R., Gholipour, H. F., Feizi, M., Nunkoo, R., \& Andargoli, A. E. (2020). International Tourism and Outbreak of Coronavirus (COVID-19): A Cross-Country Analysis. Journal of Travel Research, 1-6. DOI:10.1177/0047287520931593

Galvani, A., Lew, A. A., \& Perez, M. S. (2020). COVID-19 is expanding global consciousness and the sustainability of travel and tourism. Tourism Geographies, 22(3), 1-10. DOI:10.1080/14 616688.2020.1760924

Gössling, S., Scott, D., \& Hall, C. M. (2020). Pandemics, tourism and global change: a rapid assessment of COVID-19. Journal of Sustainable Tourism, 1-20. DOI:10.1080/09669582.202 0.1758708

Higgins-Desbiolles, F. (2020). The "war over tourism": challenges to sustainable tourism in the tourism academy after COVID-19. Journal of Sustainable Tourism, 1-19. DOI:10.1080/096 69582.2020 .1803334

Hysa, E., \& Gjergi, E. (2018). The Long Run Relationship Between Tourism And Economic Growth In Western Balkan Countries: A Panel Co-Integration Analysis. Journal of tourism - studies and research in tourism, 25(15). 1-15. 
Iatu, C., Ibănescu, B.C, Stoleriu, O.M., \& Munteanu, A. (2018). The WHS Designation - A Factor of Sustainable Tourism Growth for Romanian Rural Areas? Sustainability, 10(3), 1-12. DOI: $10.3390 / \mathrm{su} 10030626$

Isik, C., Dogru, T., \& Turk, E.S. (2017). A nexus of linear and non-linear relationships between tourism demand, renewable energy consumption, and economic growth: Theory and evidence. International Journal of Tourism Research, 20(1), 38-49. DOI: 10.1002/jtr.2151

Kalaš, B., Mirović, V., \& Pavlović, N. (2019). Profitability determinants of hotel industry in AP Vojvodina. In MODERN MANAGEMENT TOOLS AND ECONOMY OF TOURISM SECTOR IN PRESENT ERA (pp. 47-62). Association of Economists and Managers of the Balkans-UDEKOM

Khan, A., Bibi, S., Ardito, L., Lyu, J., \& Babar, Z.U. (2020). Tourism and Development in Developing Economies: A Policy Implication Perspective. Sustainability, 12(4), 1-19. DOI: $10.3390 /$ su1204168

Khan, A., Bibi, S., Ardito, L., Lyu, J., Hayat, H., \& Arif, A.M. (2020). Revisiting the Dynamics of Tourism, Economic Growth, and Environmental Pollutants in the Emerging Economies - Sustainable Tourism Policy Implications. Sustainability, 12(6), 1-23. DOI: 10.3390/ su12062533

Lapointe, D. (2020). Reconnecting tourism after COVID-19: the paradox of alterity in tourism areas. Tourism Geographies, 22(3), 1-6. DOI:10.1080/14616688.2020.1762115

Lim, C., Zhu, L., \& Koo, T.T.R. (2018). Urban redevelopment and tourism growth: Relationship between tourism infrastructure and international visitor flows. International Journal of Tourism Research, 21(2), 1-10. DOI: 10.1002/jtr.2253

Lu, C., Li, W., Pang, M., Xue, B., \& Miao, H. (2018). Quantifying the Economy-Environment Interactions in Tourism: Case of Gansu Province, China. Sustainability, 10(3), 1-21. DOI: $10.3390 /$ su10030711

Mitra, S.K. (2019). Is tourism-led growth hypothesis still valid? International Journal of Tourism Research, 21(5), 1-10. DOI: 10.1002/jtr.2285

Niewiadomski, P. (2020). COVID-19: from temporary de-globalisation to a re-discovery of tourism? Tourism Geographies, 22(3), 1-6. DOI:10.1080/14616688.2020.1757749

Ongan, S., \& Gozgor, G. (2018). Tourism demand analysis: The impact of the economic policy uncertainty on the arrival of Japanese tourists to the USA. International Journal of Tourism Research, 20(3), 308-316. DOI: 10.1002/jtr.2182

Paunović, I., Dressler, M., Mamula Nikolic, T., \& Popovic Pantic, S. (2020). Developing a Competitive and Sustainable Destination of the Future: Clusters and Predictors of Successful National-Level Destination Governance across Destination Life-Cycle. Sustainability, 12, 4066. DOI:10.3390/su12104066

Petrevska, B. (2017). Predicting tourism demand by A.R.I.M.A. models. Economic Research Ekonomska istraživanja, 30(1), 939-950. DOI: 10.1080/1331677x.2017.1314822

Polyzos, S., Samitas, A., \& Spyridou, A. E. (2020). Tourism demand and the COVID-19 pandemic: an LSTM approach. Tourism Recreation Research, 1-13. doi:10.1080/02508281.2020.17 77053

Popesku, J., \& Pavlović, D. (2013). Competitiveness of Serbia as a tourist destination: Analysis of selected key indicators. Marketing, 44(3), 199-210. DOI:10.5937/markt1303199P

Prideaux, B., Thompson, M., \& Pabel, A. (2020). Lessons from COVID-19 can prepare global tourism for the economic transformation needed to combat climate change. Tourism Geographies, 22(3), 1-12. doi:10.1080/14616688.2020.1762117

Qian, L., Shen, H., \& Law, R. (2018). Research in Sustainable Tourism: A Longitudinal Study of Articles between 2008 and 2017. Sustainability, 10(3), 1-13. DOI: 10.3390/su10030590 
Qiu, R. T. R., Park, J., Li, S., \& Song, H. (2020). Social costs of tourism during the COVID-19 pandemic. Annals of Tourism Research, 1-39, DOI:10.1016/j.annals.2020.102994

Romagosa, F. (2020). The COVID-19 crisis: Opportunities for sustainable and proximity tourism. Tourism Geographies, 22(3), 1-5. DOI:10.1080/14616688.2020.1763447

Rodríguez-Antón, J.M. \& Alonso-Almeida, M.M. (2020). COVID-19 Impacts and Recovery Strategies: The case of the Hospitality Industry in Spain. Sustainability, 12(20), 1-17. DOI: $10.3390 /$ su12208599

Saleh, A.S., Assaf, A.G., Ihalanayake, R., \& Lung, S. (2013). A Panel Cointegration Analysis of the Impact of Tourism on Economic Growth: Evidence from the Middle East Region. International Journal of Tourism Research, 17(3), 209-220. DOI: 10.1002/jtr.1976

Santamaria, D., \& Filis, G. (2019). Tourism demand and economic growth in Spain: New insights based on the yield curve. Tourism Management, 75, 447-459. DOI: 10.1016/j.tourman.2019.06.008

Seetanah, B., Sannassee, R.V., Teeroovengadum, V., \& Nunkoo, R. (2018). Air access liberalization, marketing promotion and tourism development. International Journal of Tourism Research, 21(1), 1-11. DOI: 10.1002/jtr.2242

Selimi, N., Sadiku, L., \& Sadiku, M. (2017). The Impact of Tourism on Economic Growth in the Western Balkan Countries: An Empirical Analysis. International Journal of Business and Economic Sciences Applied Research, 10(2), 19-25. DOI: 10.25103/ijbesar.102.02

Shahzad, S.J.H., Shahbaz, M., Ferrer, R., \& Kumar, R.R. (2017). Tourism-led growth hypothesis in the top ten tourist destinations: New evidence using the quantile-on-quantile approach. Tourism Management, 60, 223-232. DOI: 10.1016/j.tourman.2016.12.006

Summers, J., Cavaye, J., \& Woolcock, G. (2019). Enablers and Barriers of Tourism as a Driver of Economic and Social-cultural Growth in Remote Queensland. Economic Papers: A Journal of Applied Economics and Policy, 38(2), 1-18. DOI: 10.1111/1759-3441.12246

Tafel, M., \& Szolnoki, G. (2020). Estimating the economic impact of tourism in German wine regions. International Journal of Tourism Research, 1-12. DOI: 10.1002/jtr.2380.

Tang, C.F., \& Tan, E.C. (2013). How stable is the tourism-led growth hypothesis in Malaysia? Evidence from disaggregated tourism markets. Tourism Management, 37, 52-57. DOI: 10.1016/j. tourman.2012.12.014

Tang, C.F., Salman, A., \& Abosedra, S. (2019). Dynamic interaction of tourism, finance, and institutions in explaining growth in Asia's little dragon economies. International Journal of Tourism Research, 22(1), 1-11. DOI: 10.1002/jtr.2315

Tugcu, C.T. (2014). Tourism and economic growth nexus revisited: A panel causality analysis for the case of the Mediterranean Region. Tourism Management, 42, 207-212. DOI: 10.1016/j. tourman.2013.12.007

Uğur, N. G., \& Akbiyik, A. (2020). Impacts of COVID-19 on global tourism industry: A cross-regional comparison. Tourism Management Perspectives, 36, 1-13. DOI:10.1016/j. tmp.2020.100744

Usmani, G., Akram, V., \& Praveen, B. (2020). Tourist arrivals, international tourist expenditure, and economic growth in BRIC countries. Journal of Public Affairs, 1-8. DOI: 10.1002/ pa.2202)

Wu, T.P., \& Wu, H.C. (2018). Tourism and economic growth in Asia: A bootstrap multivariate panel Granger causality. International Journal of Tourism Research, 21(1), 1-10. DOI: $10.1002 /$ jtr.2243

Yang, Y., Altschuler, B., Liang, Z., \& Li, X. (2020). Monitoring the global COVID-19 impact on tourism: The COVID19 tourism index. Annals of Tourism Research, 1-18. DOI:10.1016/j. annals.2020.103120 
Yazdi,S.K.(2019). Structuralbreaks, internationaltourismdevelopmentandeconomic growth.Economic Research - Ekonomska istraživanja, 32(1), 1765-1776. DOI: 10.1080/1331677X.2019.1638279

Yfantidou, G., \& Matarazzo, M. (2016). The Future of Sustainable Tourism in Developing Countries. Sustainable Development, 25(6), 459-466. DOI: 10.1002/sd.1655

Zha, J., Zhu, Y., He, D., Tan, T., \& Yang, X. (2019). Sources of tourism growth in Mainland China: An extended data envelopment analysis-based decomposition analysis. International Journal of Tourism Research, 22(1), 1-17. DOI: 10.1002/jtr.2318

Zhang, S., \& Chan, E.S.W. (2018). A modernism-based interpretation of sustainable tourism. International Journal of Tourism Research, 22(2), 1-15. DOI: 10.1002/jtr.2330

Zhou, L., \& Chan, E.S.W. (2019). Motivation of tourism-induced mobility: Tourism development and the pursuit of the Chinese dream. International Journal of Tourism Research, 21(6), 1-15. DOI: $10.1002 /$ jtr.2308 